\title{
First record of Tachinaephagus zealandicus Ashmead, 1904 (Hymenoptera: Encyrtidae) parasitizing the blowfly Sarconesia chlorogaster (Wiedemann, 1830) (Diptera: Calliphoridae) in Brazil
}

\author{
Lecheta, MC. ${ }^{a *}$ and $L u z, D R .^{b}$
}

a'Laboratório de Dinâmicas Ecológicas, Departamento de Zoologia, Universidade Federal do Paraná - UFPR, Av. Cel. Francisco Heráclito dos Santos, s/n, Jardim das Américas, CP 19020, CEP 81530-980, Curitiba, PR, Brazil

${ }^{b}$ Laboratório de Biologia Comparada de Hymenoptera, Departamento de Zoologia, Universidade Federal do Paraná UFPR, Av. Cel. Francisco Heráclito dos Santos, s/n, Jardim das Américas, CP 19020, CEP 81530-980, Curitiba, PR, Brazil

*e-mail: melise.lecheta@gmail.com

Recieved: October 9, 2014 - Accepted: November 7, 2014 - Distributed: May 31, 2015

(With 1 figure)

The blowfly Sarconesia chlorogaster (Wiedemann, 1830) (Diptera: Calliphoridae) (Figure 1a) is endemic in South America and occurs in colder regions with more temperate climates. It has been recorded in: Argentina, Uruguay, Bolivia, Chile, Peru and the Southern region of Brazil (Dear, 1979). Due to the necrophagous habits of their larvae, S. chlorogaster is commonly recorded feeding on carcasses (e.g. Moura et al., 1997) and human bodies (Vairo et al., 2015). Thus, this species can help estimate the time elapsed between death and the discovery of a body, defined as postmortem interval (PMI).
Tachinaephagus zealandicus Ashmead, 1904 (Hymenoptera: Encyrtidae) is a gregarious endoparasitoid wasp that attacks the third instar of the maggots, the post feeding larvae, or the prepupae of synanthropic flies (Calliphoridae, Muscidae, Sarcophagidae) (Olton and Legner, 1974). This species, probably native to Australia and New Zealand, has been introduced into various parts of the world since the late 1960s and early 1970s (Legner and Olton, 1968) in attempts to control pest species of synanthropic Diptera. It is currently established in areas of Africa (Prinsloo, 1979), Europe (e.g. Frederickx et al., 2013), North America (e.g. Legner and Olton, 1968) and

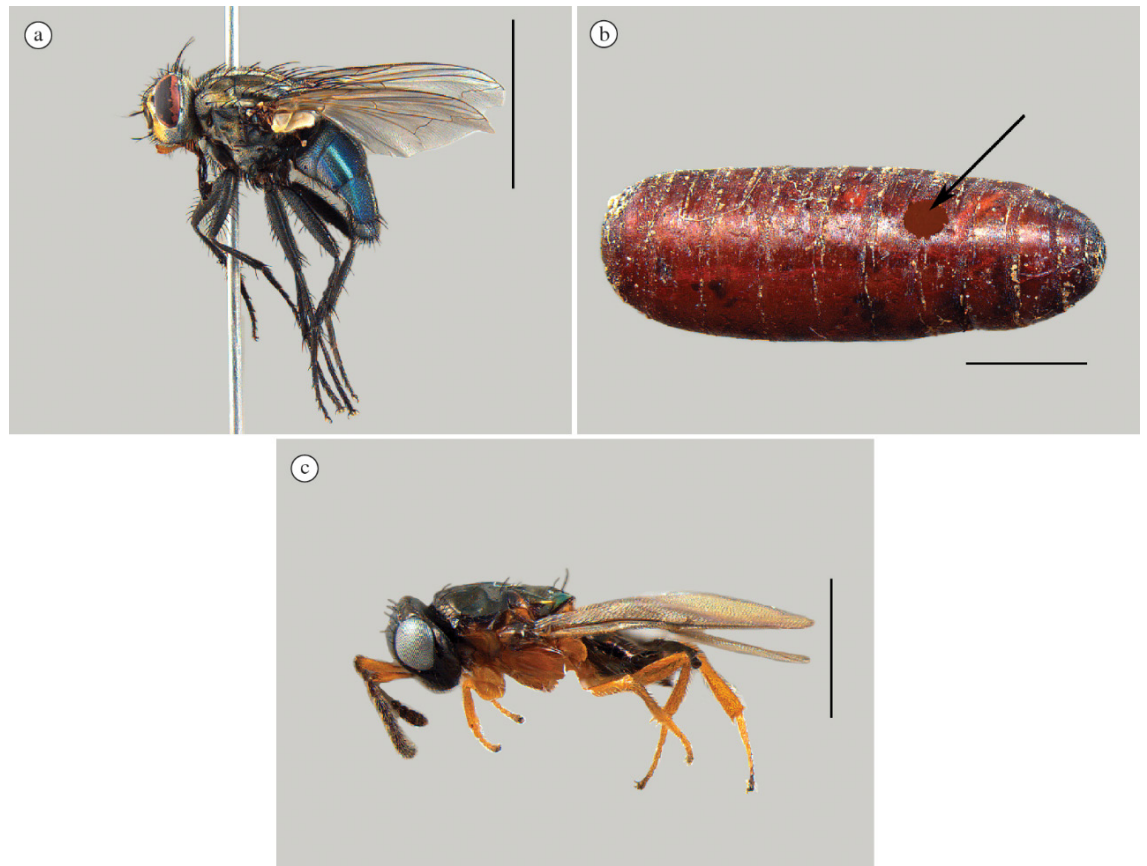

Figure 1. (a). Sarconesia chlorogaster (Wiedemann), female, lateral view, scale bar = 5mm; (b). Pupae of S. chlorogaster parasitized by Tachinaephagus zealandicus. Black arrow indicates parasitoid emergence hole, scale bar $=2 \mathrm{~mm}$; (c). T. zealandicus Ashmead, female, lateral view, scale bar $=1 \mathrm{~mm}$. 
South America. In Brazil, T. zealandicus was reported in the states of São Paulo, Minas Gerais and Rio de Janeiro parasitizing flies of the families Muscidae (e.g. Silveira et al., 1989), Sarcophagidae (Carvalho et al., 1995) and Calliphoridae. The parasitoid has been recorded attacking the following calliphorid species: Cochliomyia hominivorax (Coquerel, 1858) (Silveira et al., 1989), Chrysomya putoria (Wiedemann, 1830) (Almeida et al., 2002) and Chrysomya megacephala (Fabricius, 1794) (e.g. Carvalho et al., 2003).

Here we present the first record for T. zealandicus parasitizing $S$. chlorogaster and the genus Sarconesia and the first record of its occurrence in Paraná State.

In 2012, during a study involving colonies maintained in field conditions of $S$. chlorogaster in Curitiba $\left(25^{\circ} 25^{\prime} \mathrm{S}\right.$; $\left.49^{\circ} 14^{\prime} \mathrm{W}\right)$, Paraná State, Brazil, we noticed the presence of many parasitoids emerging from the puparium (Figure 1b) of this species. After that, in the next generation, all pupae were individualized in test tubes to confirm the occurrence of parasitoids. We observed that about $3 \%$ of pupae were parasitized and the average of parasitoids emergence were 30 individuals per pupae. Parasitoids were identified as T. zealandicus (Figure 1c) using Subba Rao (1978) key to species. Parasitism occurred in more than one generation while the colony was maintained under field conditions.

These new records presented here are valuable due to the possibility of using $S$. chlorogaster in PMI estimates based on insects, since the presence of parasitoids can either help or hinder these estimates (Holdaway and Evans, 1930; Amendt et al., 2000; Turchetto and Vanin, 2004). Thus, more studies are needed to evaluate the effect of this parasitoid on development of $S$. chlorogaster and its possible implications for PMI estimations.

\section{Acknowledgements}

We would like to thank CNPq (Conselho Nacional de Desenvolvimento Científico e Tecnológico) for financial support: MCL (CNPq: process number 141043/2012-1) and DRL (CNPq: process number 143491/2011-3).

\section{References}

ALMEIDA, MAF., PRADO, AP. and GEDEN, CJ., 2002. Influence of temperature on development time and longevity of Tachinaephagus zealandicus (Hymenoptera: Encyrtidae), and effects of nutrition and emergence order on longevity. Environmental Entomology, vol. 31, no. 2, p. 375-380. http:// dx.doi.org/10.1603/0046-225X-31.2.375.

AMENDT, J., KRETTEK, R., NIESS, C., ZEHNER, R. and BRATZKE, H., 2000. Forensic entomology in Germany. Forensic Science International, vol. 113, no. 1-3, p. 309-314. http://dx.doi. org/10.1016/S0379-0738(00)00239-5. PMid:10978642

CARVALHO, LML., LINHARES, AX. and FERREIRA DE ALMEIDA, MA., 1995. Ocorrência de microhimenópteros parasitóides associados às pupas de Sarcophagidae e Calliphoridae criadas na carcaça animal numa reserva natural de Campinas,
SP. In Anais do XV Congresso de Entomologia, 1995. Caxambu. Lavras: Editora UFLA. p. 590.

CARVALHO, AR., MELLO, RP. and D'ALMEIDA, JM., 2003. Microhimenópteros parasitóides de Chrysomya megacephala. Revista de Saude Publica, vol. 37, no. 6, p. 810-812. http:// dx.doi.org/10.1590/S0034-89102003000600019. PMid:14666314

DEAR, JP., 1979. A revision of the Toxotarsinae (Diptera, Calliphoridae). Papéis Avulsos de Zoologia, vol. 32, no. 13, p. 145-182.

FREDERICKX, C., DEKEIRSSCHIETER, J., VERHEGGEN, FJ. and HAUBRUGE, E., 2013. The community of Hymenoptera parasitizing necrophagous Diptera in an urban biotope. Journal of Insect Science (Online), vol. 13, no. 32, p. 1-14. http://dx.doi. org/10.1673/031.013.3201. PMid:23895458

HOLDAWAY, FG. and EVANS, AC., 1930. Parasitism a stimulus to pupation: Alysia manducator in relation to the host Lucilia sericata. Nature, vol. 125 , no. 3155 , p. 598-599. http://dx.doi. org/10.1038/125598a0.

LEGNER, EF. and OLTON, GS., 1968. Activity of parasites from diptera: Musca domestica, Stomoxys calcitrans, and species of Fannia, Muscina, and Ophyra. II. At sites in the Eastern Hemisphere and Pacific area. Annals of the Entomological Society of America, vol. 61, no. 5, p. 1306-1314. http://dx.doi.org/10.1093/ aesa/61.5.1306. PMid:5758059

MOURA, MO., CARVALHO, CJ. and MONTEIRO-FILHO, ELA., 1997. A preliminary analysis of insects of medico-legal importance in Curitiba, State of Paraná. Memorias do Instituto Oswaldo Cruz, vol. 92, no. 2, p. 269-274. http://dx.doi.org/10.1590/ S0074-02761997000200023. PMid:9332590

OLTON, GS. and LEGNER, EF., 1974. Biology of Tachinaephagus zealandicus (Hymenoptera: Encyrtidae), parasitoid of synanthropic Diptera. Canadian Entomologist, vol. 106, no. 8, p. 785-800. http://dx.doi.org/10.4039/Ent106785-8.

PRINSLOO, GL., 1979. On some little-known african Encyrtidae (Hymenoptera: Chalcidoidea), with new records and descriptions of genera and species. Journal of the Entomological Society of South Africa, vol. 42, no. 1, p. 17-34.

SILVEIRA, GAR., MADEIRA, NG., AZEREDO-ESPIN, AML. and PAVAN, C., 1989. Levantamento de microhimenópteros parasitóides de dípteros de importância médico-veterinária no Brasil. Memorias do Instituto Oswaldo Cruz, vol. 84, no. 4, p. 505-510. http://dx.doi.org/10.1590/S0074-02761989000800089.

SUBBA RAO, BR., 1978. A revision of Tachinaephagus Ashmead (Hymenoptera: Encyrtidae) with descriptions of four new species. Bulletin of Entomological Research, vol. 68, no. 01, p. 65-73. http://dx.doi.org/10.1017/S000748530000715X.

TURCHETTO, M. and VANIN, S., 2004. Forensic evaluations on a crime case with monospecific necrophagous fly population infected by two parasitoid species. Anil Aggrawals Internet Journal of Forensic Medicine and Toxicology, vol. 5, no. 1, p. 12-18.

VAIRO, KP., CORRÊA, RC., LECHETA, MC., CANEPARO, MF., MISE, KM., PRETI, D., CARVALHO, CJ., ALMEIDA, LM. and MOURA, MO., 2015. Forensic use of a subtropical blowfly: the first case indicating minimum postmortem interval (mPMI) in southern Brazil and first record of Sarconesia chlorogaster from a human corpse. Journal of Forensic Sciences, vol. 60, supplement 1, p. S257-S260. http://dx.doi.org/10.1111/1556-4029.12596. PMid:25425207 